\title{
Cephalotaxus griffithii Hook.f. needle extract induces cell cycle arrest, apoptosis and suppression of hTERT and hTR expression on human breast cancer cells
}

\author{
Dinesh Singh Moirangthem ${ }^{1 \dagger}$, Surbala Laishram ${ }^{1 \dagger}$, Jagat Chandra Borah ${ }^{1}$, Mohan Chandra Kalita ${ }^{2}$ and
} Narayan Chandra Talukdar ${ }^{1 *}$

\begin{abstract}
Background: Cephalotaxus spp. are known to possess anticancer potential. In this present work, for the first time the effects of $C$. griffithii needle (CGN) extracts on human cancer cells were examined.

Methods: The CGN was successively extracted with petroleum ether (PE), acetone and methanol. The extracts were tested for its effect on proliferation of cancer cells (MTT assay on HeLa, ZR751 and HepG2). Extract that showed the maximum growth inhibitory effect was subjected for mechanism of action study. These included apoptosis (morphological and DNA fragmentation assay), cell cycle (flow cytometry), caspase expression (Western blot) and activity (assay kit), p53 (western blot and TP53 siRNA interference) and telomerase expression (reverse transcriptase P(R) analysis.

Results: Among the extracts, PE extract induced maximum cytotoxicity, with highest death occurred in ZR751 cells. Since, PE extract induced cell death was highest among the CGN extracts, with maximum cancer cell death occurred in ZR751 cells; we carried out mechanism study of PE extract induced ZR751 cell death. It was observed that PE extract induced ZR751 cell death was associated with cell cycle arrest and apoptosis by activating both intrinsic and extrinsic apoptotic pathways. Knock down study revealed that p53 is essential for loss of ZR751 cell viability induced by PE extract. Further, PE extract down-regulated hTERT, hTR, and c-Myc expression. Thin layer chromatography analysis indicated the presence of unique phytochemicals in PE extract.
\end{abstract}

Conclusion: Based on the observations, we concluded that PE extract of $C$. griffithii needle contains important phyto-components with multiple cellular targets for control of breast cancer and is worthy of future studies.

Keywords: Cephalotaxus griffithii, Apoptosis, Cell cycle, Telomerase, p53

\section{Background}

Mortality due to cancer is becoming unacceptably high and is therefore a worldwide concern. Statistics indicate that the total number of cancer deaths in 2007 was 7.6 million, of which $62 \%$ were in developing countries and $38 \%$ in developed countries [1]. By 2050, 27 million new cases and 17.5 million cancer deaths are expected globally

\footnotetext{
* Correspondence: nctalukdar@yahoo.com

${ }^{\dagger}$ Equal contributors

'Institute of Bioresources and Sustainable Development, Takyelpat Institutional Area, Imphal 795001,Manipur, India

Full list of author information is available at the end of the article
}

[1]. Therefore, serious efforts have been made to reduce the threat of cancer all over the globe.

Historically, natural products have served as a rich source of lead compounds for drug development against a wide array of biological targets, including various forms of cancer. Search continues in rigorous footing to discover unexplored plants and animals as potential new sources of anticancer drugs. Since 1940, almost $75 \%$ of approved small molecules for the treatment of cancer have been either natural products, semi-synthetic derivatives of natural product scaffolds, or synthetic compounds inspired by natural products pharmacophores [2]. 
The genus Cephalotaxus has received a great level of scientific interest as it contains anticancer potential ingredients [3-6]. Homoharringtonine, an alkaloid isolated from Cephalotaxus harringtonia was recently approved by USFDA for the treatment of adult patient with chronic myeloid leukemia [7]. In view of the importance of the Cephalotaxus genus, we searched for unexplored species within this genus to check for anticancer potential components. Cephalotaxus griffithii Hook. f., a gymnosperm in the family Cephalotaxaceae, is another important species commonly known as Griffith's plum yew. It is a shrub or small tree and found up to an altitude of $2000 \mathrm{~m}$ and is distributed in North East India, western Sichuan province in China, and Myanmar [8]. C. griffithii mostly remained unexplored due to remoteness of location and limited accessibility of the habitat of this species. So far, only three studies from $C$. griffithii have been attempted. Kamil et al. [9] isolated and characterized six flavonoids, Phutdhawong et al. [10] carried out chemical analysis of volatile oil from needles of C. griffithii. Moirangthem et al. [11] analysed the biological activity of the bark extracts of $C$. griffithii.

Since plant constituents are distributed in different parts [12-14], needles of C. griffithii may also contain compounds with anticancer properties. Moreover, needles can also serve as a better source because it eliminates the risk of destruction associated with harvest of bark. In this study, we determined the effect of Cephalotaxus griffithii needle (CGN) extract on human cancer cells in terms of antiproliferation, cell cycle regulation, apoptosis induction and telomerase expression.

\section{Methods}

\section{Chemicals}

3-(4, 5-dimethyl-2-thiazolyl)-2, 5-diphenyl-tetrazolium bromide (MTT); acridine orange (AO); ethidium bromide (EB); propidium iodide (PI); and cell culture chemicals were purchased from Sigma-Aldrich Chemicals Pvt. Ltd. (Mumbai, India). Curcumin was purchased from HiMedia Laboratories Pvt. Ltd. (Mumbai, India). Proteinase-K and RNase were purchased from Bangalore Genei (Bangalore, India), and the rest of the chemicals and solvents used were of analytical grade.

\section{Plant material}

The CGNs were collected from Kangchup Hills, Manipur, India $\left(\mathrm{N} 24^{\circ} 52^{\prime} 10^{\prime}\right.$ E093 $\left.46^{\prime} 12^{\prime}\right)$ at an elevation of $1534.66 \mathrm{~m}$ above sea level. The specimen was identified by Dr. Biseshwori Thongam, Plant Systematics and Conservation Laboratory, Medicinal, Aromatic and Horticultural Plant Resources Division, Institute of Bioresources and Sustainable Development (IBSD), Manipur, India and by Dr. S.K. Verma, National Bureau of Plant Genetics Resources, Meghalaya, India. A voucher specimen (IBSD/C/ 102) has been deposited to the IBSD herbarium.

\section{Preparation of CGN extracts}

The CGNs were air dried at room temperature and powdered. The powdered needles were then exhaustively extracted successively by soaking (which prevents the loss of biological activity of some heat-sensitive ingredients) in petroleum ether $(\mathrm{PE})$, acetone $(\mathrm{ACE})$, and methanol $(\mathrm{MeOH})$ in order to fractionate the phytochemical constituents. Filtration was performed and the filtrates were concentrated in vacuo using a vacuum rotary evaporator (EYELA, Japan) and finally freeze dried (Thermo, Modulyod). The dried extracts were kept at $4^{\circ} \mathrm{C}$ until further analysis.

\section{Test sample preparation}

Solutions of the test samples for the entire study were prepared in DMSO, except for the PE extract in which the sample was prepared in 1, 4-dioxan.

\section{Cell culture}

The experimental cell lines were procured from the National Centre for Cell Science (Pune, India). HeLa and ZR751 cells were grown in DMEM (Dulbecco's modified Eagle's medium) and HepG2 was grown in RPMI-1640 medium supplemented with $10 \%(\mathrm{v} / \mathrm{v})$ heat-inactivated fetal bovine serum (FBS) and 1\% antibiotic antimycotic solution $(10,000 \mathrm{U} / \mathrm{ml}$ penicillin, $10 \mathrm{mg} / \mathrm{ml}$ streptomycin sulfate, and $25 \mu \mathrm{g} / \mathrm{ml}$ amphotericin-B), and maintained at $37^{\circ} \mathrm{C}$ in a humidified atmosphere with $5 \% \mathrm{CO}_{2} / 95 \%$ air.

\section{MTT reduction assay}

Cytotoxicity analysis was determined using the MTT assay as reported by Mosmann [15]. Cancer cells grown in T-25 culture flasks were harvested by trypsinization, plated at an approximate density of $2 \times 10^{4}$ cells/well in 96-well culture plates, and incubated for $24 \mathrm{~h}$. Next the medium from each well was removed and the cells were washed twice with Dulbecco's phosphate buffered saline (PBS). The cells were then exposed to increasing concentrations of extract $(5-160 \mu \mathrm{g} / \mathrm{ml})$ for $24 \mathrm{~h}$. After incubation, the contents were replaced with MTT dissolved in serumfree medium $(1.2 \mathrm{mM})$ after which the plates were further incubated for $3 \mathrm{~h}$. The contents were then replaced with equal amounts of DMSO to solubilise the formazan grains formed by viable cells. Finally, the absorbance was read at $570 \mathrm{~nm}$ using a multi-well plate reader (Thermo, Multiskan spectrum). The viability percentage was calculated by using the formula below:

$$
\begin{aligned}
\text { Viability } \%= & \text { Absorbance of test sample } \\
& \times 100 / \text { Absorbance of solvent control. }
\end{aligned}
$$

\section{Fluorescence microscopy}

ZR751 cells $\left(2 \times 10^{4}\right.$ cells/well $)$ were cultured in 96-well culture plates, treated with or without test samples and 
incubated for $24 \mathrm{~h}$. Staining was done using DNAintercalate fluorescent dyes EB and AO [16], and analyzed under a fluorescence microscope (Nikon, TS 100-F).

\section{DNA fragmentation assay}

For laddering experiments, ZR751 cells $\left(2 \times 10^{5}\right.$ cells/well $)$ were cultured in 6-well culture plates, treated with or without test samples and incubated for $24 \mathrm{~h}$. Cells were then harvested, washed with ice-cold PBS ( $\mathrm{pH} 7.2)$, and centrifuged at $500 \mathrm{~g}$ for $6 \mathrm{~min}$ at $4^{\circ} \mathrm{C}$. The resulting cell pellet was dispersed in $30 \mu \mathrm{l}$ of lysis buffer (10 mM EDTA; $50 \mathrm{mM}$ Tris $\mathrm{HCl}, \mathrm{pH} \mathrm{7.8;} \mathrm{1 \%} \mathrm{SDS)} \mathrm{by} \mathrm{gentle} \mathrm{vortexing.}$ $4 \mu \mathrm{l}$ of proteinase- $\mathrm{K}(10 \mu \mathrm{g} / \mu \mathrm{l})$ was then added to the above mixture, followed by incubation at $37^{\circ} \mathrm{C}$ for $1 \mathrm{~h}$. Then, $2 \mu \mathrm{l}$ of RNase $(10 \mu \mathrm{g} / \mu \mathrm{l})$ was added to the cell lysates, which were further incubated for $1 \mathrm{~h}$ at $57^{\circ} \mathrm{C}$. After incubation cell lysates were mixed with $4 \mu \mathrm{l}$ of $6 \mathrm{X}$ DNA loading dye and subjected to run at $2 \%$ agarose gel electrophoresis. The gel was then stained with ethidium bromide $(0.5 \mu \mathrm{g} / \mathrm{ml})$ and visualized under a gel documentation system (Bio-Rad).

\section{Flow cytometry}

Cell cycle analysis was carried out using PI staining [17]. ZR751 cells $\left(2 \times 10^{5}\right.$ cells/well $)$ were cultured in 6-well culture plates, treated with or without test samples for $24 \mathrm{~h}$. After incubation, cells were harvested and fixed in ice-cold $70 \%$ ethanol overnight at $-20^{\circ} \mathrm{C}$. Fixed cells were then treated with $0.5 \mathrm{ml}$ of DNA extraction buffer (192 ml of $0.2 \mathrm{M} \mathrm{Na}_{2} \mathrm{HPO}_{4}$ with $8 \mathrm{ml}$ of $0.1 \%$ Triton X-100 $(\mathrm{v} / \mathrm{v}))$ for $5 \mathrm{~min}$ at room temperature. DNA was stained with PI (0.02 mM) and incubated for $1 \mathrm{~h}$ in the dark. Flow cytometric analysis was then performed using a flow cytometer (BD FACSCaliber).

\section{Assessment of caspase activities}

Caspase- $3 / 7$, caspase- 8 and caspase- 9 activity was assayed by measuring the light intensity using an assay kit (Caspase-Glo ${ }^{\oplus}$ 3/7Assay, Caspase-Glo 8 Assay and CaspaseGlo $^{\circ} 9$ Assay, Promega) with some modification. Briefly, ZR751 cells $\left(1 \times 10^{5}\right.$ cells/well) were treated with different concentrations $(5-40 \mu \mathrm{g} / \mathrm{ml})$ of test samples for $24 \mathrm{~h}$. After incubation, cell pellets were lysed in lysis buffer (50 mM Tris- $\mathrm{HCl}$ pH 7.4, $150 \mathrm{mM} \mathrm{NaCl}, 1 \%$ NP-40, 0.1\% SDS, 2 mM EDTA, $1 \mathrm{mM}$ phenylmethylsulfonylfluoride and protease inhibitor cocktail). Equal amount of protein extract cell lysates were loaded in opaque white 96-well plates and $40 \mu \mathrm{l}$ of caspase- $3 / 7$ or caspase- 8 or caspase- 9 reaction buffer was added and incubated at room temperature for $1 \mathrm{~h}$ before measurement.

\section{RNA extraction and reverse transcriptase PCR}

The ZR751 cells $\left(2 \times 10^{5}\right.$ cells/well $)$ were cultured in 6well culture plates, treated with or without test samples for $24 \mathrm{~h}$. After incubation, total RNA was prepared using an RNeasy kit (Qiagen) and primed with random hexamers to synthesize complementary DNA using superscript II reverse transcriptase (Invitrogen) according to the manufacturer's instructions. Polymerase chain reaction (PCR) was carried out in a Mastercycler (Biorad) with specific primers (Additional file 1: Table S1). Amplification products obtained by PCR were electrophoretically separated on $1.5 \%$ agarose gel, stained with ethidium bromide $(0.5 \mu \mathrm{g} / \mathrm{ml})$ and visualized under gel documentation system (Bio-Rad).

\section{Western blot analysis}

Protein expression was carried out as per the standard protocol [18]. Briefly, ZR751 cells $\left(2 \times 10^{5}\right.$ cells/well $)$ were cultured in 6-well culture plates, treated with different concentrations $(5-40 \mu \mathrm{g} / \mathrm{ml})$ of PE extract for $24 \mathrm{~h}$. Cell pellets were lysed in lysis buffer $(50 \mathrm{mM}$ Tris$\mathrm{HCl} \mathrm{pH} \mathrm{7.4,} 150$ mM NaCl, 1\% NP-40, 0.1\% SDS, 2 mM EDTA, $1 \mathrm{mM}$ phenylmethylsulfonylfluoride and protease inhibitor cocktail). Equal amount of protein extract cell lysates were electrophoresed in SDS polyacrylamide gel and then transferred onto PVDF membranes. The membranes were subsequently incubated with primary antibodies of anti-p53, anti-BAX, anti-Bcl2, anti-caspase-3, anti-PARP, anti-cleaved PARP or anti- $\beta$-actin at room temperature for $60 \mathrm{~min}$. Antibody recognition was detected with the anti-rabbit or anti-mouse IgG linked to horseradish peroxidase at room temperature for $60 \mathrm{~min}$. Protein bands were visualized on Chemi Doc XRS Imaging System, Bio-Rad after treating with enhanced chemiluminescence reagent.

\section{siRNA interference}

p53 expression was knocked down using validated silencer TP53 siRNA (Ambion). Sequences were: sense 5'-GUAAUCUCAUGGGACGGAAtt-3' and antisense 5' - UUCCGUCCCAGUAGAUUACca-3'. For siRNA transfection experiments, ZR751 cells were plated and transfected after $24 \mathrm{~h}$ at $\sim 70 \%$ confluency by using Lipofectactamine RNAiMAX transfection agent, according to the manufacturer's instructions. After $24 \mathrm{~h}$ of transfection, cells were exposed to different concentrations of PE extract for $24 \mathrm{~h}$ prior to analysis of protein expression by western blot or cell viability by MTT assay. A nontargeting control siRNA (SilencerH Negative ControlAmbion) was used as transfection control.

\section{Thin layer chromatography}

Equal concentration $(16 \mu \mathrm{g} / \mu \mathrm{l})$ of CGN extracts were loaded on silica gel 60 TLC aluminium sheets. The plates were developed using petroleum ether: ethyl acetate $(5: 2)$. The spots were located by exposing the plates to UV light (365 nm). 


\section{Statistical analysis}

The values are presented as mean \pm SD (standard deviation). Comparision between two groups were done by $t$-test and multiple comparisons between more than two groups were performed by one-way ANOVA supplemented with Tukey's HSD test. Values at $P<0.05$ were considered to indicate statistical significance.

\section{Results}

\section{CGN extracts treatment induces death of human cancer} cells

Effects of the three CGN extracts in six graded doses on three tumor cell lines (HeLa, HepG2 and ZR751) are shown in Figure 1. All the extracts induced death of tested cancer cells. The relative number of surviving cells decreased in a dose-dependent manner and the magnitude of effects varied depending on the cancer cells tested. Among the extracts, PE extract exhibited the maximum antiproliferative effect in all the cancer cells tested followed by ACE and $\mathrm{MeOH}$ extract $(P<0.01-0.001)$. PE extract induced maximum cell death in ZR751 cells $(P<0.001)$ (Figure 1 ; Table 1) indicating the selective cytotoxicity of PE extract towards breast cancer cells.

\section{CGN PE extract treatment induces apoptosis of human} breast cancer cells

Morphological changes of ZR751 cells caused by PE extract were analyzed using fluorescence microscope (Figure 2A) after staining the cells with AO/EB. The untreated ZR751 cells showed no contact inhibition with large nucleus. PE extract incubation led to dramatic alterations of the normal cellular architecture of ZR751 cells, and showed characteristic features of apoptosis. These included contact inhibition, nuclear contraction and nuclear fragmentation. Correspondingly, nucleosomal DNA fragmentation of ZR751 cells was also clearly visible due to the treatment with PE extract (Figure 2B).

\section{CGN PE extract treatment induces cell cycle arrest in human breast cancer cells}

The effect of PE extract on cell cycle distribution in ZR751 cells are shown in Figure 3. Treatment of ZR751 cells with $P E$ extract resulted in significant increase of $G_{2}$ phase cells compared to the control $(P<0.001)$. The accumulation of cells in $G_{2}$ increased in a dose dependent manner. This increase was coupled with the decreased percentage of cells in $S$ and $G_{1}$ phase $(P<0.001)$ except in $5 \mu \mathrm{g} / \mathrm{ml}$ treatment. Further, the sub- $\mathrm{G}_{0} / \mathrm{G}_{1}$ population, a biochemical marker of apoptosis [19] was significantly higher in the PE extract treated cells than the untreated control $(P<0.001)$. The increase in sub- $\mathrm{G}_{0} / \mathrm{G}_{1}$ population was concentration dependent. A statistically significant positive correlation was observed between the $G_{2}$ and sub- $\mathrm{G}_{0} / \mathrm{G}_{1}$ cell accumulation $(\mathrm{r}=0.905 ; P<0.01)$. Overall, these results indicate that PE extract induced ZR751 cell death may be due to the induction of $G_{2}$ cell cycle arrest and subsequent apoptotic process.

\section{CGN PE extract treatment activates both intrinsic and} extrinsic pathways in human breast cancer cells

Treatment with PE extract up-regulated p53 and BAX expression and down-regulated $\mathrm{Bcl} 2$ expression in ZR751 cells (Figure 4A). Further, incubation of ZR751 cells with

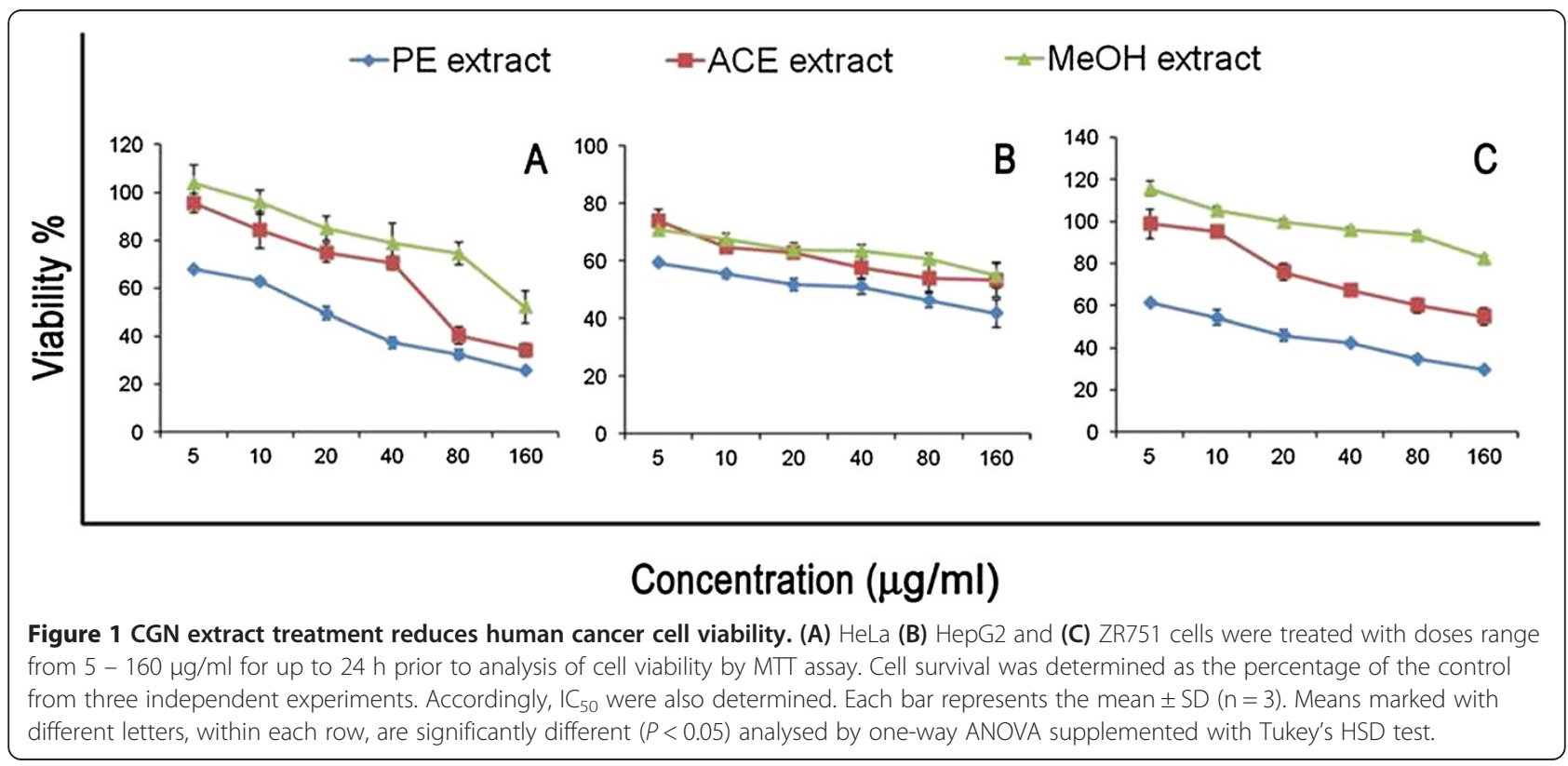


Table 1 IC 50 values of Cephalotaxus griffithii needle extracts treatment on cancer cells

\begin{tabular}{llll}
\hline $\begin{array}{l}\text { Cancer } \\
\text { cell }\end{array}$ & \multicolumn{3}{c}{ Extract $(\boldsymbol{\mu g} / \mathbf{m l})$} \\
\cline { 2 - 4 } & PE & ACE & MeOH \\
\hline HeLa & $83.5 \pm 7.2 p$ & $143 \pm 10.2 q$ & $205.2 \pm 16.2 r$ \\
HepG2 & $66.3 \pm 6.1 p$ & $128.9 \pm 13.1 \mathrm{q}$ & $275.3 \pm 19.1 r$ \\
ZR751 & $22.3 \pm 3.9 p$ & $151.4 \pm 13.8 q$ & $343 \pm 16.2 r$ \\
\hline
\end{tabular}

Means marked with different letters, within each row, are significantly different $(P<0.05)$ analysed by one-way ANOVA supplemented with Tukey's HSD test.

PE extract resulted in the significant increase in expression level $(P<0.05)$ of caspase-3 (Figure $4 \mathrm{~A}$ and $4 \mathrm{~B})$. Correspondingly, the activity of caspase- 3 was also significantly increased $(P<0.001)$. A significant increase was observed even at the lowest test concentration $(5 \mu \mathrm{g} / \mathrm{ml})$. However, no significant dose dependent activity of caspase- 3 was observed among the treated concentrations (Figure 4B). The presence of activated caspase- 3 was also confirmed based on the degradation of PARP (a DNA repair enzyme), into its characteristic $89 \mathrm{kDa}$ fragment, produced as a result of cleavage by caspase-3 during apoptosis (Figure 4A). Treatment of ZR751 cells with PE extract also resulted in the increased activity of caspase- 8 and -9 , initiator caspases, upstream activators of caspase-3/7, suggesting the involvement of both extrinsic and intrinsic apoptotic pathways. The activity of both caspase- 8 and caspase- 9 were increased in a dose dependent manner (Figure 4B). p53 is essential for loss of cell viability induced by CGN PE extract in human breast cancer cells

The effect of p53 expression on antiproliferative activity of PE extract is shown in Figure 5 Silencing p53 expression resulted in significant change in the growth inhibition of PE extract on ZR751 cells. Comparing to cells with normal p53 expression, the antiproliferative activity was significantly lower in cells with silenced p53 gene (Figure 5).

\section{CGN PE extract treatment down-regulates hTERT, hTR and} c-Myc expression in human breast cancer cells

PE extract treatment decreased hTERT and hTR mRNA levels in a concentration dependent manner but had no effect on TEP-1 expressions (Figure 6) of ZR751 cells. A significant down-regulation of hTERT and hTR levels were observed due to treatment of cells at $20 \mu \mathrm{g} / \mathrm{ml}$ and $40 \mu \mathrm{g} / \mathrm{ml}$ concentrations relative to that in untreated cells. Application of PE extract also significantly downregulated c-Myc expression in a dose-dependent manner with a significant reduction of c-Myc expression seen in the last two highest concentrations (Figure 6).

\section{CGN PE extract contains unique phytochemicals}

TLC profile of CGN extracts is shown in Figure 7. The chromatogram pattern of PE extract was distinctly different as compared with the other two extracts. Three spots settled at the Rf value 0.78, 0.71 and 0.61 observed in PE extract were not visible in case of $\mathrm{ACE}$ and $\mathrm{MeOH}$

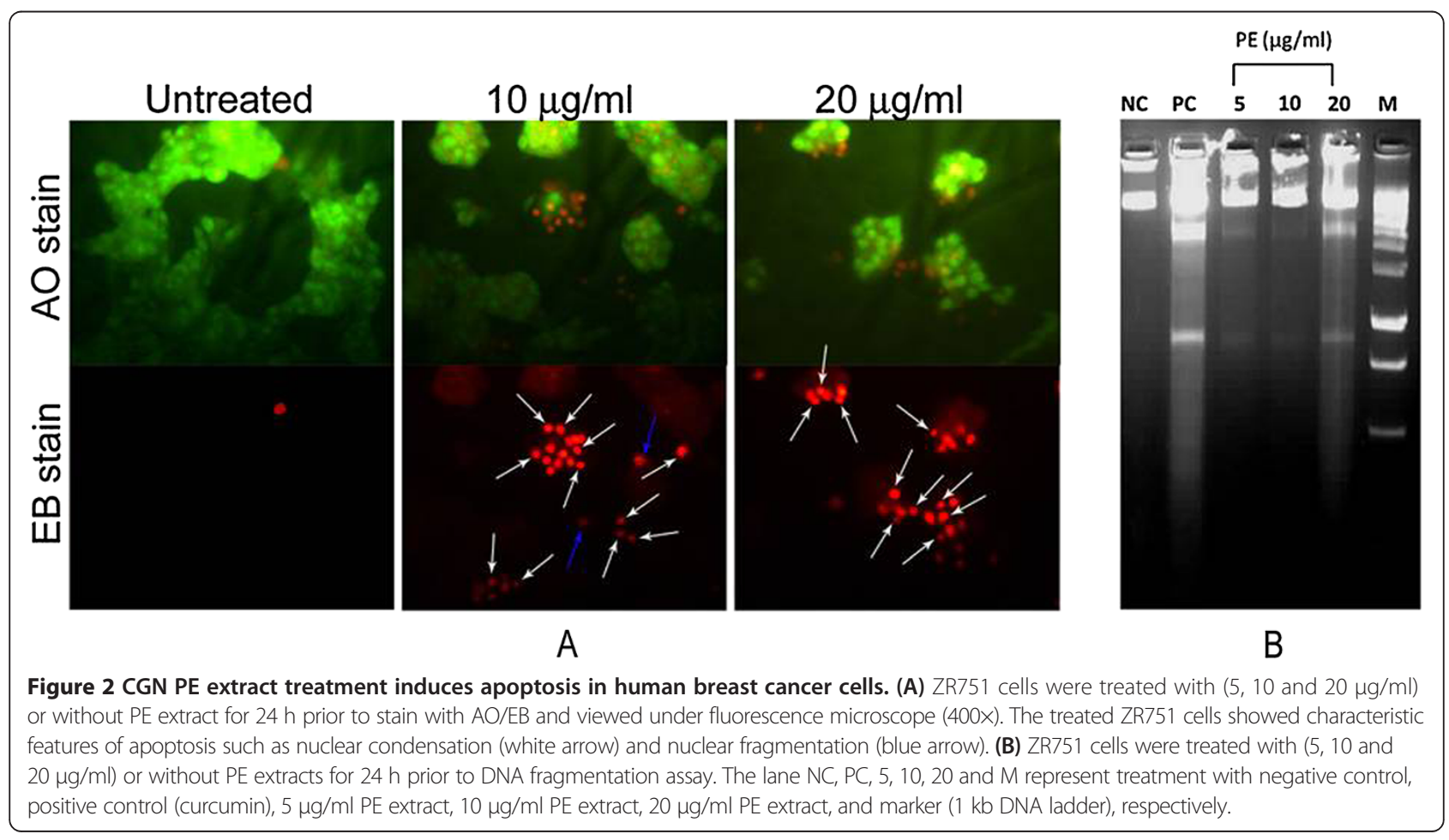



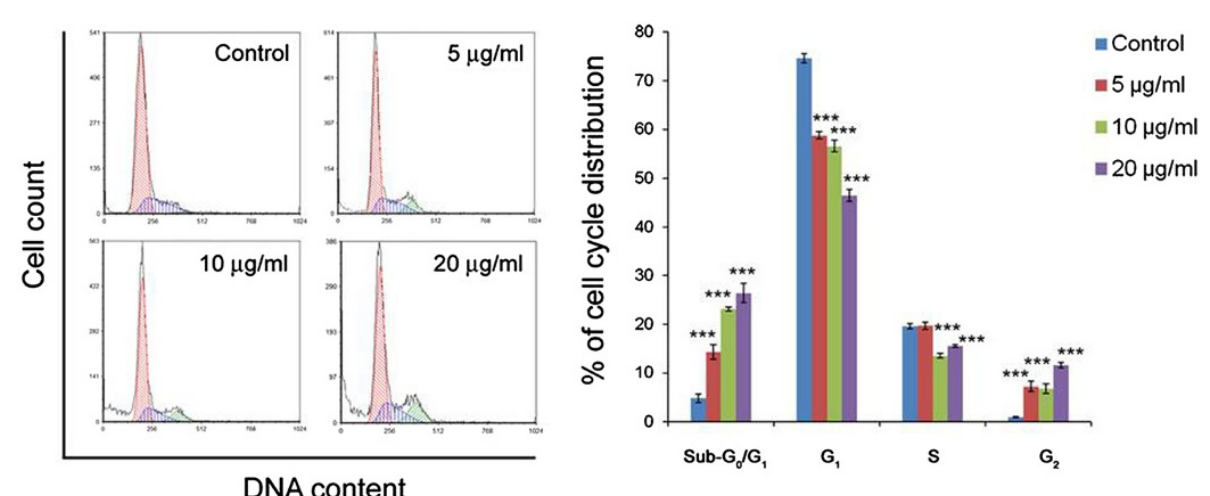

Figure 3 CGN PE extract induces cell cycle arrest in human breast cancer cells. ZR751 cells were treated with (5, 10 and $20 \mu \mathrm{g} / \mathrm{ml})$ or without PE extract for $24 \mathrm{~h}$ prior to cell cycle analysis. Each bar represents the mean $\pm \mathrm{SD}(n=3)$. Data denoted ${ }^{* *}(P<0.001)$ are significant compared to controls, as analysed by $t$-test.

extracts. There were similarities in few spots at Rf value $0.49,0.32$ and 0.16 , although the intensity of the spots was much higher in PE extract.

\section{Discussion}

This is the first report on the effect of CGN on human malignant tumor cells. For this study, the CGN was successively extracted with $\mathrm{PE}, \mathrm{ACE}$ and $\mathrm{MeOH}$. The antiproliferative activity was performed using MTT reduction assay on three different cancer cell lines (HeLa, HepG2 and ZR751 cells) to check the efficacy of the extracts in reducing the survival rate of the cancer cells. Irrespective of the extracts, the antiproliferative activity was found to be concentration dependent. It was also observed that the antiproliferative activity of the extracts were different and specific towards the cell type. Overall, PE extract induced the maximum cancer cell death followed by in ACE and $\mathrm{MeOH}$ extract. PE extract showed the highest growth inhibition towards ZR751 cells followed by HepG2 and HeLa cells. Our earlier study on C. griffithii bark extracts, observed that PE extract showed the least growth inhibitory effect [11] on HeLa cells. In that study, the highest antiproliferative activity was found in ACE extract treatment. This suggests that the cytotoxic components

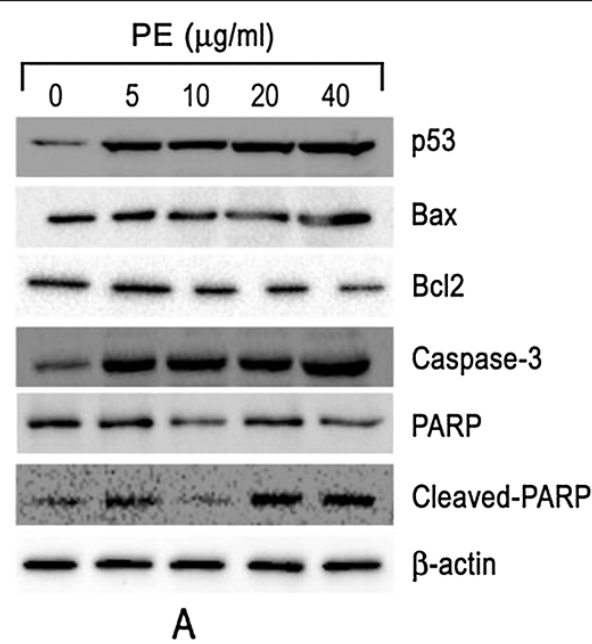

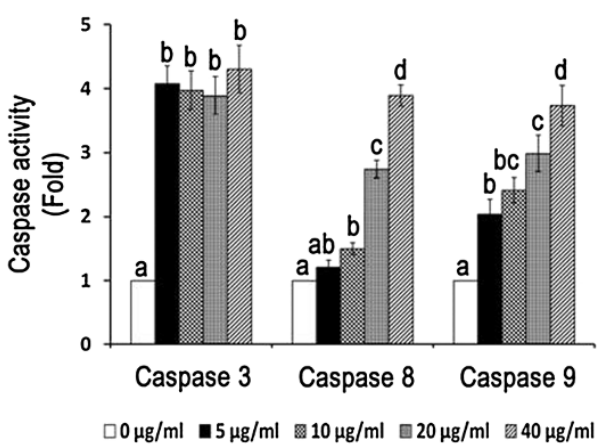

B

Figure 4 CGN PE extract treatment causes caspase dependent apoptotic cell death in human breast cancer cells. (A) ZR751 cells were treated with $(5-40 \mu \mathrm{g} / \mathrm{ml})$ or without PE extract for up to $24 \mathrm{~h}$. Protein expression of p53, BAX, Bcl2, caspase-3, PARP and cleaved-PARP was determined by western blot. $\beta$ - actin was used as loading control (B) ZR751 cells were treated with (5 - $40 \mu \mathrm{g} / \mathrm{ml})$ or without PE extract for up to $24 \mathrm{~h}$ prior to caspase-3, caspase-8 and caspase-9 activity assay. Each bar represents the mean \pm SD $(n=3)$. Bars marked without a common letter within each caspase activity are significantly different $(P<0.05)$ analysed by one-way ANOVA supplemented with Tukey's HSD test. 


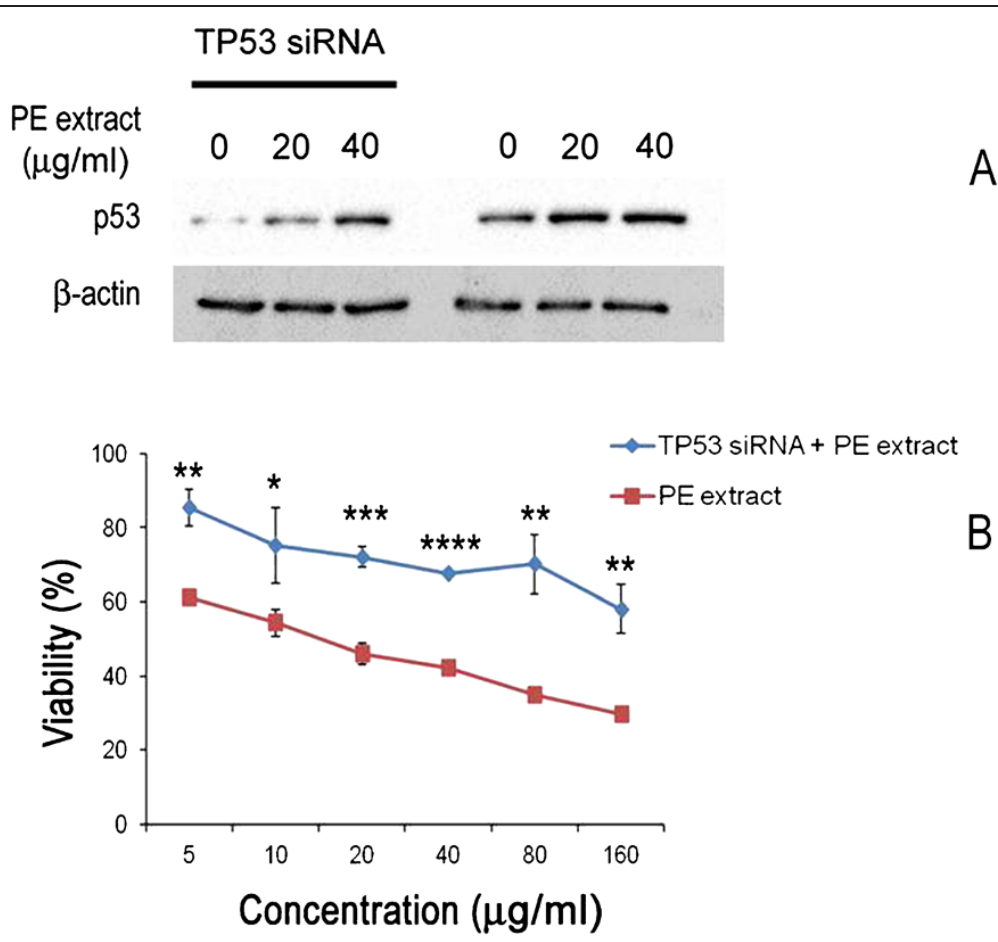

Figure 5 CGN PE extract induced cellular death is dependent on p53 expression in human breast cancer cells. ZR751 cells were transfected with TP53 siRNA for $24 \mathrm{~h}$. After transfection, cells were exposed to different concentrations of PE extract for $24 \mathrm{~h}$ prior to analysis of (A) p53 expression by western blot or (B) cell viability by MTT assay. Each bar represents the mean \pm SD $(n=3)$. Data denoted ${ }^{*}(P<0.05)$, **(P<0.01), ${ }^{* * *}(P<0.001)$ and ${ }^{* * * *}(P<0.0001)$ are significantly different compared to PE extract treatment alone (without TP53 siRNA treatment) between the same treatment concentration analysed by $t$-test.

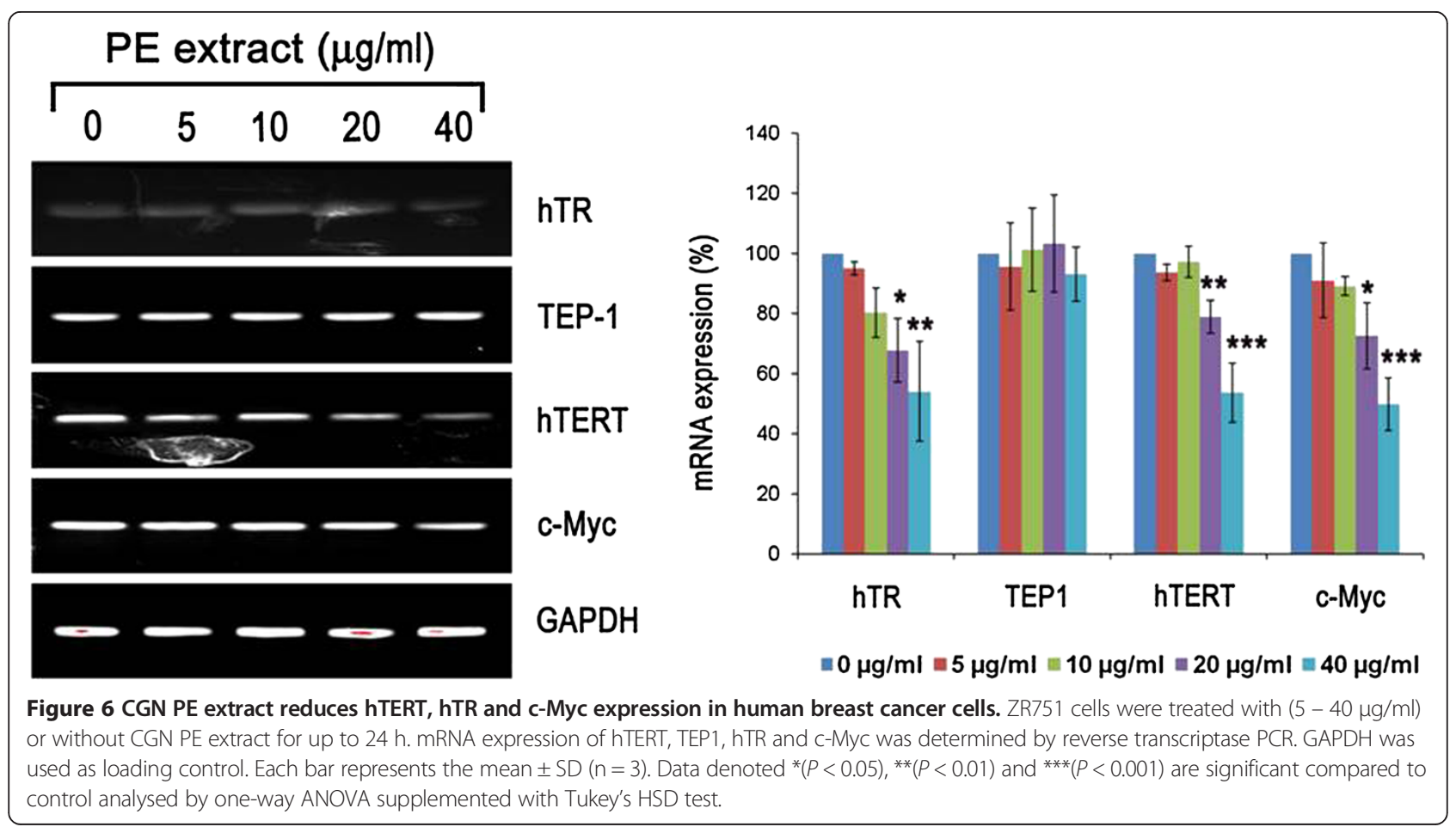




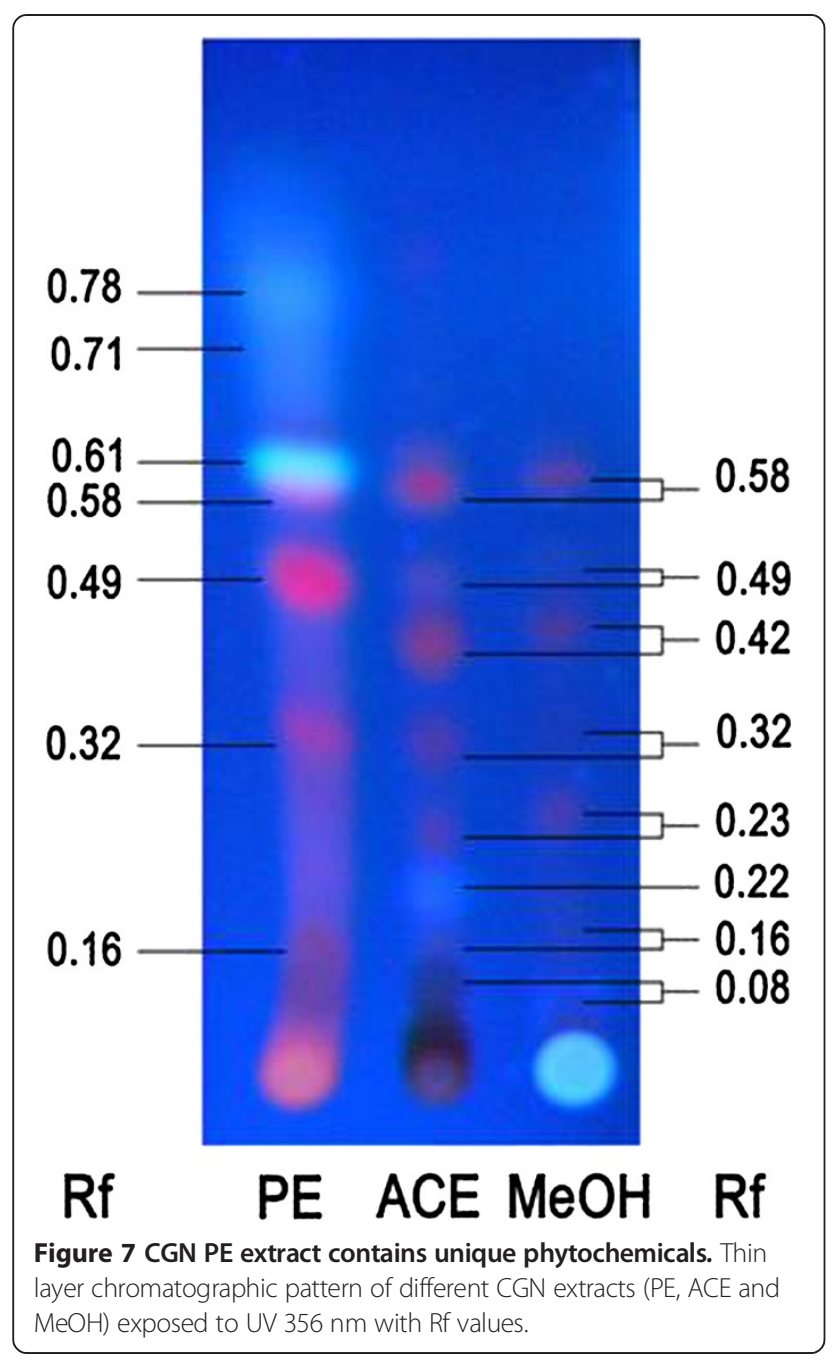

present in the needles and bark of C. griffithii are chemically different.

Since, PE extract induced cell death was highest among the CGN extracts, with maximum cancer cell death occurred in ZR751 cells; we carried out mechanism study of PE extract induced ZR751 cell death. Generally, anticancer agents have been reported to induce cell death by blocking cell cycle progression and triggering tumor cell apoptosis [20-22]. Therefore, cell cycle arrest and the induction of apoptosis in cancer cells become the major indicators of anticancer effects. To ascertain whether PE extract induced cytotoxicity on ZR751 cells was mediated through apoptosis and cell cycle arrest; morphological, biochemical, and cell cycle analysis were carried out. In the morphological study, most of the ZR751 cells showed characteristic features of apoptosis such as nuclear contraction, nuclear fragmentation and contact inhibition due to treatment with PE extract. Biochemically, apoptosis is characterized by activation of endogenous nucleases and fragmentation of DNA [23] which we observed in the DNA fragmentation assay on ZR751 cells after treatment with PE extract. Moreover, these fragmented nucleosomal DNA bands were very conspicuous as the concentration of PE extract increased. Further, cell cycle analysis of treated ZR751 cells with PE extract caused cell cycle arrest at $G_{2}$ phase $(P<0.001)$. Furthermore, the sub- $G_{0} / G_{1}$ population, a biochemical marker of apoptosis [24] with hypo-diploid DNA, was significantly higher in PE extract treated cells as compared to untreated control. A positive correlation was observed between the $G_{2}$ cell built up and sub- $G_{0} / G_{1}$ cell accumulation suggesting that the cause of ZR751 cell death by PE extract may be due to the induction of $G_{2}$ cell cycle arrest and subsequent apoptotic process.

The p53 protein is an essential molecule that arrests cells with damaged DNA in $G_{2}$, allowing time for DNA repair before the cell tries to enter the $M$ phase. But if the cell is committed to division or the damage cannot be repaired, then p53 triggers a program cell death through the extrinsic and intrinsic apoptotic pathways $[25,26]$. In this study, treatment of PE extract on ZR751 cells, which express a functional wild-type p53 protein [27] caused a significant increased of p53 protein expression. Further, we observed that p53 expression has a direct impact on the antiproliferative activity of ZR751 cells. When the p53 gene expression was knockdown, there was a significant reduction in the cell death induced by PE extract. This suggests that p53 is an essential target for PE extract of CGN. Among the genes activated by p53 is the pro-apoptotic protein Bax, a key member of the Bcl2 family proteins [28], and the importance of the Bax to drug-induced apoptosis is becoming increasingly apparent [29]. Bax forms a homodimer and releases cytochrome $\mathrm{c}$ from the mitochondria, which results in caspase- 9 activation. Treatment with PE extract on ZR751 cells caused an increase in the expression of Bax which was inversely mirrored by a decrease in $\mathrm{Bcl} 2$ expression, an antiapoptotic regulator. The increase in Bax expression are strongly indicative of increased p53 function whether by increased expression or activity as Bax expression can also be regulated by p53 [30].

The effector proteins in the apoptotic pathway are enzymes called caspases are a family of cysteine proteases that cleave target sites at aspartate residues, constitute key components of the apoptotic pathway. Caspase- 9 triggered mitochondria pathway and the caspase- 8 mediated death receptor-mediated pathway are two pathways involved in apoptosis. The caspase -9 and -8 are upstream caspases that converge to caspase-3 [26], a key effector molecule in the caspase-dependent cell apoptosis pathway that cleaves a number of cellular proteins including PARP, leading to DNA fragmentation and triggering apoptosis [31]. In this study, treatments with PE extract on ZR751 cells upregulated the expression of caspase -8 , caspase- 9 and 
caspase- 3 with the cleavage of PARP. These suggest that PE extract induced apoptosis via the activation of both caspase-dependent pathway through caspase- 9 triggered mitochondria pathway and caspase- 8 mediated death receptor pathway.

It has been reported that resistance to apoptosis is associated with telomerase expression in human cancer cells [32]. Telomeres are essential units that prevent the loss of genetic information. In normal somatic cells, which show little or no telomerase activity in synthesizing new telomeres at the ends of replicating chromosomes, the telomeric DNA progressively shortens with each cell division. Extensive shortening of telomeres is detected as a kind of DNA damage; as a result p53 is activated, leading to p53-triggered apoptosis. Most tumor cells, despite their rapid proliferation rate, stabilises by expressing telomerase [33]. It has been reported that telomerase has anti-apoptotic role and up-regulation of telomerase helps cancer cells to resist against therapeutic drug-mediated cell death. Since, telomerase is essential for a tumor cell to become immortal, and specific inhibitors of telomerase have been suggested as a new strategy for cancer therapy [34-36]. Telomere length in humans is primarily controlled by three major components, hTERT, TEP-1, and hTR. It has been shown that hTERT mRNA expression correlates with telomerase activity in human breast cancer cells [37]. In this study, we observed that application of PE extract on ZR751 cells downregulated the expression of hTERT and hTR. These suggest that suppression of telomerase may also be one of the causes for ZR751 cell death upon treatment with PE extract of CGN. Expression of hTERT is strictly regulated at the transcriptional level by several transcription factors, particularly, c-Myc [38]. Correspondingly, with the hTERT down-regulation, the expression level of c-Myc in ZR751 cells was down-regulated after PE extract treatment.

TLC analysis revealed the presence of unique phytochemicals in the PE extract suggesting that the differences and concentration of phytochemicals in the PE extract was responsible for producing the maximum antiproliferative effect on the cancer cells.

\section{Conclusion}

Based on our results, we concluded that CGN contain bioactive components responsible for inducing antiproliferation, cell cycle arrest, apoptosis and telomerase suppression. Among the extracts, PE extract exhibited the highest cytotoxic effect on cancer cells. PE extract induced death of ZR751 cells by acting to multiple targets viz. cell cycle arrest, apoptosis and suppression of telomerase. These results call for further chemical characterization of PE extract of C. griffithii needle for isolation of active antineoplastic principle.

\section{Additional file}

Additional file 1: Table S1. Details of the primers used for the amplification.

\section{Abbreviations}

ACE: Acetone; AO: Acridine orange; BAX: BCl-2-like protein; $\mathrm{BCl}-2$ : B-cell lymphoma 2; CGN: C. griffithii needle; EB: Ethidium bromide; FBS: Fetal bovine serum; hRT: Human telomerase RNA component; hTERT: Human telomerase reverse transcriptase; MeOH: Methanol; MTT: 3-(4, 5-dimethyl-2-thiazolyl)-2, 5diphenyl-tetrazolium bromide; PARP: Poly (ADP-ribose) Polymerase; PE: Petroleum ether; PI: Propidium iodide; TEP-1: Telomerase-Associated Protein; USFDA: United States Food and Drug Administration.

\section{Competing interests}

The authors declare that they have no competing interests.

\section{Authors' contributions}

DSM, SL, JCB, MCK and NCT conceived and designed the experiments. DSM and SL performed the experiments: DSM, SL, JCB, MCK and NCT analyzed the data and wrote the paper. All authors read and approved the final manuscript.

\section{Acknowledgements}

The senior author thanks the Institute of Bioresources and Sustainable Development (IBSD), Imphal and Department of Biotechnology, Government of India for the Ph.D.-JRF fellowship. The authors would like to express their utmost gratitude and appreciation to Mr. Dia Eraijao which helps in finding the plant material.

\section{Author details}

${ }^{1}$ Institute of Bioresources and Sustainable Development, Takyelpat Institutional Area, Imphal 795001,Manipur, India. ${ }^{2}$ Department of Biotechnology, Gauhati University, Guwahati 781014, Assam, India.

Received: 30 April 2014 Accepted: 13 August 2014

Published: 18 August 2014

\section{References}

1. American Cancer Society: Global Cancer Facts and Figures 2007. Atlanta: American Cancer Society; 2007.

2. Newman DJ, Cragg GM: Natural products as sources of new drugs over the 30 years from 1981 to 2010. J Nat Prod 2003, 75:311-335.

3. Takano I, Yasuda I, Nishijima M, Hitotsuyanagi Y, Takeya K, Itokawa H: Drupangtonine, a novel antileukemic alkaloid from Cephalotaxus harringtonia var. drupacea. Bioorg Med Chem Lett 1996, 6:1689-1690.

4. Takano I, Yasuda I, Nishijima M, Yanagi Y, Takeya K, Itokawa H: Ester-type Cephalotaxus alkaloids from Cephalotaxus harringtonia var. Drupacea. Phytochemistry 1997, 44:735-738.

5. Kuo YH, Lin CH, Hwang SY, Shen YC, Lee YL, Shyh-Yuan L: A novel cytotoxic C-methylated biflavone from the stem of Cephalotaxus wilsoniana. Chem Pharm Bull 2000, 48:440-441.

6. Morita H, Yoshinaga M, Kobayashi J: Cephalezomines G, H, J, K, L. and M, new alkaloids from Cephalotaxus harringtonia var. nana. Tetrahedron 2002, 58:5489-5495.

7. U.S. Food and Drug Administration: FDA approves Synribo for chronic myelogenous leukemia. 2012, Available: http://www.fda.gov/NewsEvents/ Newsroom/ PressAnnouncements/ucm325895.htm. Accessed 14 January 2014.

8. Uma S: Blooming potential of the detached shoots of Cephalotaxus griffithii Hook. f. Curr Sci 2008, 95:320-321.

9. Kamil M, Khan NA, Ahmad I, liyas M, Rahman W: Chemical constituents of Cephalotaxus griffithii. J Indian Chem Soc 1982, 59:1199.

10. Phutdhawong W, Korth J, Budhasukh D, Pyne SG: Volatile components from Cephalotaxus griffithii growing in northern Thailand. Flavour Fragr J 2002, 179:153-155.

11. Moirangthem DS, Talukdar NC, Kasoju N, Bora U: Antioxidant, antibacterial, cytotoxic, and apoptotic activity of stem bark extracts of Cephalotaxus griffithii Hook. F. BMC Complement Altern Med 2012, 12:30. doi:10.1186/1472-6882-12-30.

12. Kayani SA, Masood A, Achakzai AKK, Anbreen S: Distribution of secondary metabolites in plants of quetta-balochistan. Pak J Bot 2007, 39:1173-1179. 
13. Achakzai AKK, Achakzai P, Masood A, Kayani SA, Tareen RB: Response of plant parts and age on the distribution of secondary metabolites on plants found in quetta. Pak J Bot 2009, 41:2129-2135.

14. Hyder PW, Fredrickson EL, Estell RE, Tellez M, Gibben RP: Distribution and concentration of total phenolics, condensed tannins, and nordihydroguaiaretic acid (NDGA) in creosotebush (Larrea tridentate). Biochem Sys Ecol 2002, 30:905-912.

15. Mosmann T: Rapid colorimetric assay for cellular growth and survival: application to proliferation and cytotoxicity assays. J Immunol Methods 1983, 65:55-63.

16. Ribble D, Goldstein NB, Norris DA, Shellman YG: A simple technique for quantifying apoptosis in 96-well plates. BMC Biotechnol 2005, 5:12. doi:10.1186/1472-6750-5-12.

17. Riccardi C, Nicoletti I: Analysis of apoptosis by propidium iodide staining and flow cytometry. Nat Protoc 2006, 1:1458-1461.

18. Fido J, Tatham S, Shewry R: Western blotting analysis. Methods Mol Biol 1995, 49:423-437.

19. Fuke H, Shiraki K, Sugimoto K, Tanaka J, Beppu T, Yoneda K, Yamamoto N, Ito K, Masuya M, Takei Y: Jak inhibitor induces $S$ phase cell-cycle arrest and augments TRAIL-induced apoptosis in human hepatocellular carcinoma cells. Biochem Biophys Res Commun 2007, 363:738-744.

20. Chang JS, Son JK, Li G, Oh EJ, Kim JY, Park SH, Bae JT, Kim HJ, Lee IS, Kim OM, Kozukue N, Han JS, Hirose M, Lee KR: Inhibition of cell cycle progression on HepG2 cells by hypsiziprenol A9, isolated from Hypsizigus marmoreus. Cancer Lett 2004, 212:7-14.

21. Ye M, Liu JK, Lu ZX, Zhao Y, Liu SF, Li LL, Tan M, Weng XX, Li W, Cao Y: Grifolin, a potential antitumor natural product from the mushroom Albatrellus confluens, inhibits tumor cell growth by inducing apoptosis in vitro. FEBS Lett 2005, 579:3437-3443.

22. Hsieh TC, Wu P, Park S, Wu JM: Induction of cell cycle changes and modulation of apoptogenic/anti-apoptotic and extracellular signaling regulatory protein expression by water extracts of I'm-YunityTM (PSP). BMC Complement Altern Med 2006, 6:30. doi:10.1186/1472-6882-6-30.

23. Bortner CD, Oldenburg NB, Cidlowski JA: The role of DNA fragmentation in apoptosis. Trends Cell Biol 1995, 5:21-26.

24. Yu J, Liu H, Lei J, Tan W, Hu X, Zou G: Antitumor activity of chloroform fraction of Scutellaria barbata and its active constituents. Phytother Res 2007, 21:817-822.

25. Taylor WR, Stark GR: Regulation of the G2/M transition by p53. Oncogene 2001, 20:1803-1815

26. Ghobrial IM, Witzig TE, Adjei AA: Targeting apoptosis pathways in cancer therapy. CA Cancer J Clin 2005, 55:178-194.

27. Bartek J, lggo R, Gannon J, Lane DP: Genetic and immunochemical analysis of mutant p53 in human breast cancer cell lines. Oncogene 1990, 5:893-909.

28. Yu J, Zhang L, Hwang PM, Kinzler KW, Vogelstein B: PUMA induces the rapid apoptosis of colorectal cancer cells. Mol Cell 2001, 7:673-682

29. Makin G, Dive C: Apoptosis and cancer chemotherapy. Trends Cell Biol 2001, 11:S22-S26.

30. Murray-Zmijewski F, Slee EA, Lu X: A complex barcode underlies the heterogeneous response of p53 to stress. Nat Rev Mol Cell Biol 2008, 9:702-712.

31. Scovassi Al, Poirier GG: Poly (ADP-ribosylation) and apoptosis. Mol Cell Biochem 1999, 199:125-127.

32. Mandal M, Kumar R: Bcl2 modulates telomerase activity. J Biol Chem 1997, 72:14183-14187

33. Hahn WC, Stewart SA, Brooks MW, York SG, Eaton E, Kurachi A, Beijersbergen RL, Knoll JH, Meyerson M, Weinberg RA: Inhibition of telomerase limits the growth of human cancer cells. Nat Med 1999, 5:1164-1170.

34. Saretzki G: Telomerase, mitochondria and oxidative stress. Exp Gerontol 2009, 44:485-492.

35. Hahn WC, Meyerson M: Telomerase activation, cellular immortalization and cancer. Ann Med 2001, 33:123-129.

36. Oulton R, Harrington L: Telomeres, telomerase, and cancer: life on the edge of genomic stability. Curr Opin Oncol 2000, 12:74-81.
37. Kirkpatrick KL, Clark G, Ghilchick M, Newbold RF, Mokbel K: hTERT mRNA expression correlates with telomerase activity in human breast cancer. Eur J Surg Oncol 2003, 29:321-326.

38. Casillas MA, Brotherton SL, Andrews LG, Ruppert JM, Tollefsbol TO: Induction of endogenous telomerase (hTERT) by c-Myc in WI-38 fibroblasts transformed with specific genetic elements. Gene 2003, 316:57-65.

doi:10.1186/1472-6882-14-305

Cite this article as: Moirangthem et al: Cephalotaxus griffithii Hook.f. needle extract induces cell cycle arrest, apoptosis and suppression of hTERT and hTR expression on human breast cancer cells. BMC

Complementary and Alternative Medicine 2014 14:305

\section{Submit your next manuscript to BioMed Central and take full advantage of:}

- Convenient online submission

- Thorough peer review

- No space constraints or color figure charges

- Immediate publication on acceptance

- Inclusion in PubMed, CAS, Scopus and Google Scholar

- Research which is freely available for redistribution

Submit your manuscript at www.biomedcentral.com/submit
C Biomed Central 